\title{
HEMOLITIČKA BOLEST NOVORODENČETAH DIREKTNI COOMBS TEST
}

\author{
Ornela Stojčić ${ }^{1}$, Marijana Marijanović1 ${ }^{1}$ Jadranka Knežević ${ }^{1}$ \\ ${ }^{1}$ Transfuzijski centar Sveučilišna klinička bolnica Mostar \\ Rad je primljen 05.10. 2016. \\ Rad je recenziran 04.11.2016. \\ Rad je prihvaćen 08.11.2016.
}

\section{SAŽETAK}

UVOD: Hemolitička bolest novorođenčeta je bolest u kojoj je život eritrocita novorođenčeta skraćen zbog djelovanja specifičnih protutijela nastalih u organizmu majke, a izravna je posljedica imune destrukcije fetalnih eritrocita. Direktni coombs test je test kojim se dokazuje prisutnost odnosno odsutnost protutijela ili komplementa koji oblažu stanice, koristi se za dokazivanje eritrocita in vivo obloženih protutijelima. Direktni coombs test je prva pretraga nakon poroda koja može upozoriti na razvoj teških hemolitičkih bolesti novorođenčeta. Novorođenče i aloimunizirana majka moraju se ispitati neposredno nakon poroda kako bi što ranije odredio rizik za nastanak Hemolitičke bolesti novorođenčeta i utvrditi radi li se o ABO ili Rh D, odnosno ostalim rjeđim protutijelima.

CILJ: Ukazati na važnost imunohematoloških ispitivanja u trudnoći zbog pravovremenog dokazivanja antieritrocitnih protutijela i liječenja.

METODE I MATERIJALI: Podatci su prikupljeni iz arhive protokola Odsjeka za Imunohematološka ispitivanja Transfuzijskog centra Sveučilišne kliničke bolnice Mostar.

REZULTATI: U pismohrani odsjeka za Imunohematološka ispitivanja Transfuzijskog centra SKB Mostar u 2015. godini urađeno je 1026 direktna coombs testa (DCT) za novorođenčad RhD negativnih majki i majki 0 krve grupe, od toga je 34 (4\%) DCT -a bilo pozitivno gdje je urađena elucija (postupak gdje se protutijela odvajaju od antigena). Elucijom je pronađeno da se 24 (70 \%) novorođenčadi radi o RhD imunizaciji i njih 10 ( $30 \%$ ) je ABO Hemolitička bolest novorođenčeta. ZAKLJUČAK: Hemolitička bolest novorođenčeta može se liječiti. U teškim HBN uzrokovanim visokim titroom protutijela porođaj se provocira prije vremena jer su u tom slučaju oštećenja jetre mnogo manje i provodi se liječenje novorođenčeta eksangvinotransfuzijama. Svaku trudnicu prije poroda je od iznimne važnosti potrebno testirati na prisustvo iregularnih protutijela i voditi kontrole tijekom trudnoće testiranja istih.

Ključne riječi: hemolitička bolest novorođenčeta, direktni coombs test

Adresa autora za korespondenciju:

Ornela Stojčić, dipl.med.sestra

e-mail: ornelastojcic74@gmail.com

\section{UVOD}

Dijete je posebno biće koje je slično ocu i majci jer je polovica genskog koda naslijeđena od oca, a polovica od majke što znači da se na fetalnima krvnim stanicama nalaze i očevi i majčini antigeni. Tijekom trudnoće i prilikom porođaja pojedine fetalne krvne stanice prolaze kroz posteljicu i ulaze u majčin krvotok i obratno majčina protutijela prolaze posteljicu i ulaze u fetalni krvotok. Hemolitička bolest u novorođenčeta nastaje zbog ubrzane razgradnje fetalnih eritrocita majčinim protutijelima u tijeku fetalnog života i nakon porođaja. Hemolitička bolest

novorođenčeta (HBN) je bolest u kojoj je život eritrocita novorođenčeta skraćen zbog djelovanja specifičnih protutijela nastalih u organizmu majke, a izravna je posljedica imune destrukcije fetalnih eritrocita. Fetalni eritrociti ulaze u majčin krvotok i potiču stvaranje protutijela protiv očevih antigena na fetalnim eritrocitima, majčina protutijela prolaze kroz posteljicu i u djetetovom krvotoku vežu se za njegove eritrocite ubrzavajući njihovu razgradnju u jetri i slezeni. Hemolitičku bolest novorođenčeta mogu uzrokovati sva protutijela koja su klase IgG. RhD imunizacija je najčešća imunizacija, a 
hemolitička bolest novorođenčeta izazvana anti D protutijelima može imati vrlo tešku kliničku sliku. HBN može biti uzorkovana i anti A i anti B protutijelima i protutijelima druge specifičnosti.

Direktni coombs test (DCT) jeste test kojim se dokazuje prisutnost odnosno odsutnost protutijela ili komplementa koji oblažu stanice, koristi se za dokazivanje eritrocita in vivo obloženih protutijelima. DCT je prva pretraga nakon poroda koja može upozoriti na razvoj teških hemolitičkih bolesti novorođenčeta. Novorođenče i aloimunizirana majka moraju se ispitati neposredno nakon poroda kako bi što ranije odredio rizik za nastanak $\mathrm{HBN}$ i utvrditi da li se radi o $\mathrm{ABO}$ ili $\mathrm{Rh} \mathrm{D}$, odnosno ostalim rjeđim protutijela.

$\mathrm{Na}$ eritrocitima je prisutan veliki broj antigena. Većina njih su integralni dijelovi membrane, a manji dio je apsorbiran iz okolne plazme na eritrocitnu površinu. Dosad je otkriveno više od 640 specifičnih eritrocitnih antigena, a oko 300 ih je svrstano u 27 sustava krvnih grupa. Geni koji reguliraju sintezu eritrocitnih antigena nasljeđuju se prema Mendelovim zakonima. Većinom su koodominantni, odnosno na eritrocitima se iskazuju antigeni naslijeđeni od obaju roditelja. Recesivni se geni fenotipski ne iskazuju u prisutnosti dominantnih gena (1).

Svi antigeni krvnih grupa nemaju jednako kliničko značenje. $U$ Rh sustavu je najimunogeničniji $\mathrm{RhD}$ antigen, zatim slijede antigeni sustava Kell (K), Kidd (Jk ) i Duffy (Fy) (2). Anti-Rh D protutijela najčešća su klinički značajna imuna aloprotutijela. Posljedica su Rh D pozitivnih transfuzija i trudnoća, IgG su klase i uzrokuju hemolitičke transfuzijske reakcije (HTR) i teške oblike hemolitičke bolesti novorođenčeta (HBN) (3). Anti-D protutijela su činila oko 3/4 otkrivenih protutijela do uvođenja profilakse RhD imunizacije u trudnoći 1970. godine (4). Otada je zamjetna tendencija porasta učestalosti protutijela drugih specifičnosti. Sad na anti-D otpada $1 / 3$ klinički značajnih protutijela $(5,6)$.

Kell sustav antigena je posebice značajan zbog imunogeničnosti najvažnijeg antigena po kojem je cijeli sustav dobio ime. Kell antigen je otkriven 1946. godine kad je dokazana HBN uzrokovana anti-Kell protutijelom. U Kell sustav je svrstano 24 antigena i svi su ograničeni na eritrocitnu membranu, osim $\mathrm{Kx}$ koji se nalazi i na membrani granulocita (3). Najvažniji su antigeni Kell (K) i Chellano (k). Učestalost K antigena u bijelaca je oko $9 \%$, a u crnaca $2 \%$. Kell negativne osobe se mogu imunizirati transfuzijom Kell pozitivne krvi, a u žena do imunizacije može doći i tijekom trudnoće s Kell pozitivnim fetusom. Kell imunizacija može uzrokovati HBN i u prvoj trudnoći (8). Učestalost anti-K kao uzroka HBN-a slijedi odmah iza anti-RhD (3).

Kell antigeni su glikoproteini i javljaju se već u 10. tjednu gestacije. Izraženi su na progenitorskim stanicama eritropoeze. Tijekom 80 -ih godina prošlog stoljeća uočen je različit mehanizam djelovanja anti-D i anti-K aloprotutijela. HBN uzrokovan anti-K protutijelima posljedica je supresije eritropoeze, a manje hemolize fetalnih eritrocita (10). Osobitost je ovih protutijela inhibicija eritropoeze, zbog čega u perifernoj krvi fetusa nije izražena retikulocitoza i eritroblastoza (11). Eritrocitni prekursori budu razoreni u vrlo ranoj fazi sazrijevanja, kad je količina hemoglobina u njima mala, i zbog toga destrukcija eritrocita ne dovodi do porasta bilirubina $u$ amnijskoj tekućini. Naime, koncentracija bilirubina u amnijskoj tekućini i broj retikulocita fetusa nisu proporcionalni jačini anemije $(1,2)$. I titar protutijela je u slaboj korelaciji s jačinom anemije, pa se teški oblici mogu javiti i pri titru 1:8, pa čak 1:2 $(1,3)$.

Cilj rada je ukazati na važnost imunohematoloških ispitivanja u trudnoći zbog pravovremenog dokazivanja antieritrocitnih protutijela i liječenja.

\section{METODE I MATERIJALI}

Podatci su prikupljeni iz arhive protokola Odsjeka za Imunohematološka ispitivanja Transfuzijskog centra Sveučilišne kliničke bolnice Mostar (SKB) za 2015. godinu.

Podatci su obrađeni u programu Microsoft Office Excel (inačica 11.0., Microsoft Corporation, Redmond, WA, SAD). Svi statistički podatci su izraženi u postotcima koji su prikazani putem grafova i tablica, a izračunati su u programu Excel 2007. Retrospektivno su analizirani podaci o rezultatima testiranja neonatusa na $\mathrm{ABO}$ krvnu grupu, $\mathrm{RhD}$ antigen $\mathrm{i}$ DCT (polispecifični i monospecifični), dobiveni iz 
protokola. Uzorci krvi iz pupčanika ili vene novorođenčeta testirani su gel metodom u kartici DiaClon $\mathrm{ABO} / \mathrm{Rh}$ for Newborns DVI+ (monoclonal antibodies, BioRad) konfiguracije A, B, AB, DVI+, ctl, DCT. Na ovaj način utvrđena je ABO krvnogrupna pripadnost $(\mathrm{O}, \mathrm{A}, \mathrm{B}, \mathrm{AB})$ Skraćenice DCT - direktni antiglobulinski test, IAT - indirektni antiglobulinski test IgG - imunoglobulin G, IgM - imunoglobulin $\mathrm{M}, \mathrm{HBN}$ - hemolitička bolest novorođenčeta.

\section{REZULTATI}

U pismohrani odsjeka za Imunihematološka ispitivanja Transfuzijskog centra SKB Mostar u 2015 godini urađeno je 1026 direktna coombs testa (DCT) za novorođenčad $\mathrm{RhD}$ neg majki i majki 0 krve grupe, od toga je 34 (4\%) DCT -a bilo pozitivno gdje je uradena elucija (postupak gdje se protutijela odvajaju od antigena). Elucijom je pronađeno da se 24 ( $70 \%)$ novorođenčadi radi o $\mathrm{RhD}$ imunizaciji i njih 10 (30 \%) je ABO Hemolitička bolest novorođenčeta.

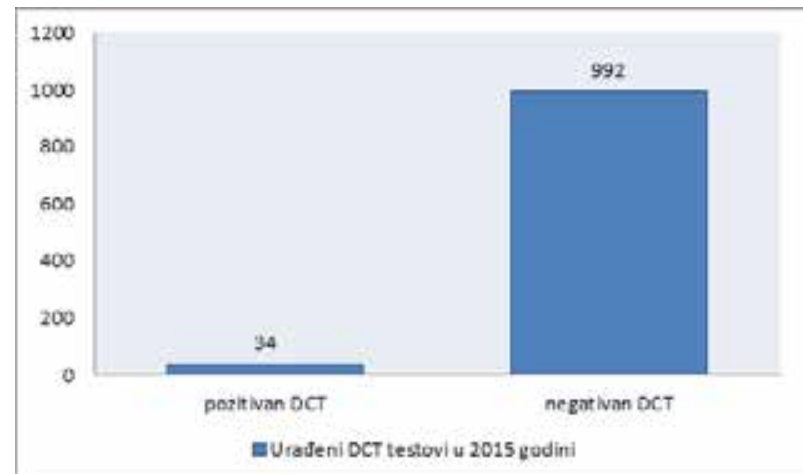

Grafikon 1. Pregled pozitivnih i negativnih DCT testova tijekom $2015 \mathrm{~g}$.

U 2015 godini je urađeno 1026 DCT testa gdje je njih 34 (4 \%) bilo pozitivno.

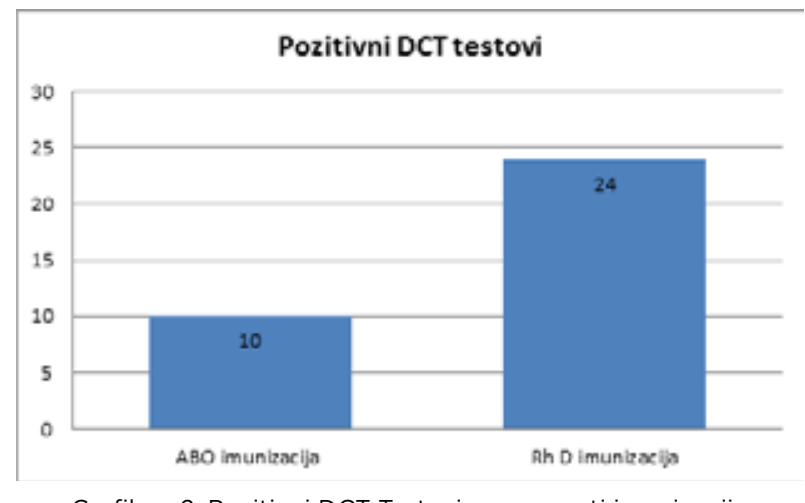

Grafikon 2. Pozitivni DCT Testovi prema vrsti imunizacije
Od ukupno 34 pozitivna direktna coombs testa njih 10 (30\%) se radi o $\mathrm{ABO}$ imunizaciji, a njih 24 (70 \%) o Rh D imunizaciji.

\section{RASPRAVA}

Fetalni eritrociti mogu se dokazati u majčinom krvotoku vrlo rano u trudnoći. Zbog starenja posteljice transplacentarno krvarenje znatnije izraženo $\mathrm{u}$ posljednjem tromjesečju trudnoće, a osobito tijekom porođaja. Prema podatcima iz literature slična istraživanja su provedena u Zavodu a transfuziju krvi Vojvodine 2011. godine gdje je tijekom godine testirano 3313 novorođenčadi od čega su dobiveni sljedeći rezultati: negativan DAT kod 3148 (95\%) neonatusa; pozitivan DCT kod 165 (5 \%). Uspoređujući ove rezultate $s$ testiranjima u Transfuzijskom centru SKB Mostar vidimo da je tek za 1\% manje pozitivnih DCT testova (14).

Transplancentarna krvarenja može da izazove amniocenteza, intrauterino uzimanje fetalne krvi, spontani i umjetno izazvani pobačaj. Majčina imunizacija najčešće nastaje $u$ tijeku porođaja zbog ulaska djetetovih eritrocita u majčin krvotok. Fetalne eritrocite obložene majčinim protutijelima razgrađuju makrofagi slezene. Zbog razgradnje eritrocita nastaje anemija i pojačano stvaranje eritrocita u jetri (fetalna eritroblastoza). jako pojačana eritropoeza u jetri uzrokuje oštećenje jetrenih stanica, poremećaj jetrene funkcije i smanjenje sinteze albumina, dolazi do generaliziranih edema. Pojačana razgradnja eritrocita dovodi do porasta bilirubina. Za hemolitičku bolest novorođenčeta najkarakterističniji je nalaz pozitivnog direktnog antiglobulinskog testa (DCT) s novorođenčetovim eritrocitima. Prema preporukama Vijeća europe u našem Transfuzijskom centru SKB Mostar DCT se radi svakom novorođenčetu rođenom od $\mathrm{RhD}$ negativnih majki i majki 0 krvne grupe u roku 72 sata od poroda zbog pravovremenog djelovanja i identificiranja mogućeg pozitivnog DCT - a i otkrivanja vrste protutijela.

HBN se može liječiti stoga je važno pravovremeno određivanje specifičnosti protutijela. Kod teških oblika HBN uzorkovanih visokim titrom protutijela porođaj se provocira prije vremena jer su u to vrijeme oštećenja jetre mnogo manja i započinje se 
liječenje anemije eksangvinotransfuzijama $\mathrm{O} R \mathrm{Rh}$ negativnom krvi. Danas se to može raditi $0 \mathrm{RhD}$ negativnim eritrocitima $\mathrm{u} A \mathrm{~B}$ RhD negativnoj plazmi. To je jeden od vodećih razloga zbog kojeg se kod svake trudnice tijekom trudnoće ispituje prisutnost iregularnih protutijela i pravovremeno djelovanje $\mathrm{u}$ cilju prepoznavanja nastanka hemolitičke bolesti novorođenčeta.

Aloimunizacija u trudnoći uzrokuje hemolitičku bolest djeteta koja u najtežim slučajevima može uzrokovati hidrops fetusa. Dijete se najčešće rađa s teškom anemijom, dok je hiperbilirubinemija umjerena ili nije izražena $(1,4)$. Kad se u trudnice dijagnosticira imunizacija i ako postoji mogućnost nastanka HBN-a, potrebna je intenzivna multidisciplinarna skrb, koja uključuje opstetričara, neonatologa i transfuziologa. Potrebno je saznati podatke o prethodnim trudnoćama, porođajima, transfuzijama krvi te odrediti titar protutijela u serumu majke i krvnu grupu djetetova oca $(1,5,6)$.

\section{ZAKLJUČAK}

HBN se može liječiti stoga je važno pravovremeno određivanje specifičnosti protutijela Teška fetalna anemija se liječi intrauternim transfuzijama, a $\mathrm{u}$ slučajevima imunizacija s rizikom ranog razvoja hidropsa učinkovite su i recidivirajući plazmafereze majke $(2,3)$. Istraživanje je pokazalo da pravovremeno testiranje novorođenčadi i njihovih majki tijekom trudnoće doprinose pravovremenom otkrivanju postojanja senzibilizacije pojedenim specifičnim protutijelom i poduzimanja mjera liječenja i praćenja s ciljem sprečavanja negativnih posljedica na novorođenče.

\section{LITERATURA}

1. Grgičević D. Transfuzijska medicina u kliničkoj praksi. Zagreb: Medicinska naklada; 2006.

2. Mesarić J, Jakšić B. Trombocitopenije: dijagnostika i terapijski pristup. Zagreb: Medicinska naklada; 2009.

3. Grgičević D, Vuk T. Imunohematologija i transfuzijska medicina. Zagreb: Medicinska naklada; 2000.
4. Vuk T. Upravljanje kvalitetom u transfuzijskoj djelatnosti: Zagreb: Hrvatski zavod za transfuzijsku medicinu; 2002.

5. Council of Europe Publishing. Preporuke za pripravu,uporabu i osiguranje kvalitete krvnih pripravaka. 17 izd. 2013.

6. Golubić Čepulić B. Profilaksa RhD imunizacije u trudnoći. Zavod za kliničku transfuziologiju. Klinički zavod za laboratorijsku dijagnostiku. KBC Zagreb. 2001

7. Golubić Ćepulić B. Izvori grešaka i njihova kontrola: Model upravljanja neželjenim događajima u kliničkoj transfuziologiji (disertacija). Zagreb: Medicinski fakultet Sveučilišta u Zagrebu; 2011.

8. Ratić D. Transfuzijska medicina. 2009. Dostupno na: http://www.slideshare.net/radenovic/ transfuzijska-medicina-online-teaj. Accessed 9. march 2013. (Preuzeto 21.09.2016)

9. Cambic C.R, Scavone B, McCarthy R.J, Eisenberg P, Sanchez E.M, Sullivan J, i sur.. A retrospective study of positive antibody screens at delivery in Rh-negative parturients.Can J Anesth/J Can Anesth. 2010; 57: 811-6.

10. Koelewijn J, Vrijkotte TGM, van der Schoot C, Bonsel GJ, de Haas M. Effect of screening for red cell antibodies, other than anti-D, to detect hemolytic disease of the fetus and newborn: a population study in the Netherlands. Transfusion. 2008; 48: 941-52.

11.Kenneth J. Moise Jr.. Non-anti-D antibodies in red-cell alloimmunization. European Journal of Obstetrics \& Gynecology and Reproductive Biology. 2000;92:75-81.

12.Dillon A, Chaudhari T, Crispin Ph, Shadbolt B, Kent A. Has anti-D prophylaxis increased the rate of positive direct antiglobulin test results and can the direct antiglobulin test predict need for phototherapy in $\mathrm{Rh} / \mathrm{ABO}$ incompatibility? Journal of Paediatrics and Child Health. 2011;47:40-43.

13. Geaghan M.Sh.Diagnostic Laboratory Technologies for the Fetus and Neonate with Isoimmunization. Seminars in Perinatology. 2011;35:14854.

14.Bujandrić N. Značaj imunohematološkog testiranja u neonatolnom periodu. Med Pregl. 
2013;317-321. Dostupno na: http://scindeks-clanci.ceon.rs/data/pdf/0025-8105/2013/002581051308317B.pdf (preuzeto 29.09.2016)

15. Tadić S. Uloga transfuzioloških laboratorija u antenatalnoj i perinatalnoj zaštiti trudnica. Bilten za transfuziologiju. 2010;56.1-2.

16. Šuput-Tomaš L, Paunović M, Janković-Oreščanin B, Burić G. Učestalost stvaranja iregularnih antieritrocitnih antitela kod trudnica. Bilten za transfuziologiju. 2007;53:1-2.
17. Gavrančić T, Milanović M, Gavrančić B. (2012) Učestalost različitih vrsta antitela kod trudnica sa pozitivnim indirektnim antiglobulinskim testom. Timočki medicinski glasnik. 2012;37:1,

18. Jakšić B, Labar B, Grgičević D. Hematologija i transfuziologija Zagreb:Jumena; 1989.

19. Hrvatski zavod za transfuzijsku medicinu. Dostupno na: http://www.hztm.hr/ (preuzeto 13.09.2016.) 


\title{
HEMOLYTIC DISEASE OF THE NEWBORNH DIRECT COOMBS TEST
}

\author{
Ornela Stojčić́ ${ }^{1}$, Marijana Marijanović1 ${ }^{1}$ Jadranka Knežević1 \\ ${ }^{1}$ Transfusion Center, University Clinical Hospital Mostar
}

\begin{abstract}
INTRODUCTION: Hemolytic disease of the newborn is a disease in which the red blood cells of a newborn are shortened due to the effect of specific antibodies generated in the mother's body, a direct consequence of immune destruction of fetal red blood cells. Direct Coombs test is a test which detects the presence or absence of antibodies or complements that line the cells; it is used for detection of red blood cells in vivo lined with antibodies. Direct Coombs test is the first test after giving birth that can draw attention to the development of severe hemolytic disease of the newborn. The newborn and aluminum immunized mother must be tested immediately in order to determine the risk of hemolytic disease of the newborn as early as possible and determine whether they are $\mathrm{ABO}$ and $\mathrm{RhD}$, or other rare antibodies.

OBJECTIVE: Emphasize the importance of immunohaematological testing during pregnancy in order to diagnose the existence of antierythrocytic antibodies and its treatment.

METHODS AND MATERIALS: The data was collected from the Department for Immunohaematological testing of the Transfusion Center at the University Clinical Hospital in Mostar.

RESULTS: From the archives of the Department for Immunohaematological testing of the Transfusion Center at the University Clinical Hospital in Mostar, from 2015, we have found that 1026 direct Coombs test (DCT) for newborn RhD negative mothers and mothers with blood type 0 were collected, of which 34 (4\%) were positive DCTs preformed with elution (a procedure where the antibodies are separated from the antigen). With the elution procedure we found that 24 (70\%) infants have $\mathrm{Rh}$ immunization and 10 of the infants (30\%) have the hemolytic disease of the newborn (ABO).

CONCLUSION: The Hemolytic disease of the newborn can be treated. In severe HDN cases caused by high antibodies, delivery is induced because in this case we have less liver damage and the treatment of the newborn is done with exchange transfusions. It is of great importance to test each pregnant woman for presence of irregular antibodies and make control tests during pregnancy.
\end{abstract}

Key words: hemolytic disease of the newborn, Direct Coombs test

Correspondence:

Ornela Stojčić

e-mail: ornelastojcic74@gmail.com 